\title{
Insights into the Electrochemistry of Deposition of Boron from KCl-KF-NaBF 4 Melt
}

\author{
Rahul Pal ${ }^{a, *}$ and S. Anthonysamy ${ }^{b}$ \\ ${ }^{a}$ Department of Chemistry, School of Chemical Sciences \& Pharmacy, \\ Central University of Rajasthan, Bandarsindri, Kishangarh 305 817, India \\ ${ }^{b}$ Materials Chemistry Division, Indira Gandhi Centre for Atomic Research, \\ Kalpakkam 603 102, India
}

Received 10 May 2014; accepted 2 March 2015

\begin{abstract}
Electrochemical reduction of boron from boron containing fluoroborate species present in $\mathrm{KCl}(81.54 \mathrm{~mol} \%)-\mathrm{KF}(18.45 \mathrm{~mol} \%)-\mathrm{NaBF}_{4}\left(1.67 \times 10^{-4} \mathrm{~mol} \mathrm{~cm}{ }^{-4}\right)$ melt on a platinum electrode was studied by cyclic voltammetry and chronoamperometry. These studies were carried out over the temperature range 1073 - $1123 \mathrm{~K}$. Boron-containing electroactive species is shown to reduce quasi-reversibly at low scan rates $\left(v<0.1 \mathrm{Vs}^{-1}\right)$ and irreversibly at higher scan rates $\left(>0.1 \mathrm{~V} \mathrm{~s}^{-1}\right)$ through a single-step three-electron process $(\mathrm{B}(\mathrm{III})+3 \mathrm{e} \rightarrow \mathrm{B})$. The transfer and diffusion coefficients of the electroactive species was measured for sodium fluoroborate in $\mathrm{KCl}-\mathrm{KF}$ melt over the temperature range $1073-1123 \mathrm{~K}$.
\end{abstract}

Keywords: Sodium fluoroborate; Cyclic voltammetry; Chronoamperometry; Diffusion coefficient; Melt.

\section{Introduction}

Boron carbide containing boron enriched in ${ }^{10} \mathrm{~B}$ isotope (67 at.\%) will be used in the control rods of the Indian Prototype Fast Breeder Reactor (PFBR) [1]. An indigenous process developed for fabricating high-density boron carbide pellets for this application envisages the synthesis of boron carbide from enriched boron by reacting it with carbon [2]. A high temperature $(1073 \mathrm{~K})$ molten salt electrolysis process was developed for the synthesis of high purity boron [3 - 5] suitable for control rod application in fast reactors. The electrolyte employed is a melt comprising $\mathrm{KCl}(72.96 \mathrm{~mol} \%), \mathrm{KBF}_{4}(11.04 \mathrm{~mol} \%)$ and $\mathrm{KF}(16 \mathrm{~mol} \%)$

\footnotetext{
* Corresponding author. E-mail address: rahul.pal@curaj.ac.in
} 
[3]. In order to have a more fundamental insight into the process with different melt compositions, a detailed experimental programme is currently being pursued at the Indira Gandhi Centre for Atomic Research (IGCAR), Kalpakkam, India. The electrochemistry of $\mathrm{KCl}-\mathrm{KF}_{-} \mathrm{KBF}_{4}\left(1.6 \times 10^{-4}\right.$ to $\left.7.73 \times 10^{-4}\right)$ melts has been reported in our previous study [5]. A systematic study on boron deposition from other alkali metal fluoroborates in $\mathrm{KCl}-\mathrm{KF}$ melt has not been reported yet.

The electrochemistry of boron is being studied since 1925 due to its nuclear and non-nuclear industrial applications [6-9]. Researchers have studied electrodeposition of elemental boron from various boron containing melts [1022]. In this context fluoroborate containing melts have been extensively studied [23-30]. The reduction of $\mathrm{B}(\mathrm{III})$ in $\mathrm{NaCl}-\mathrm{KCl}-\mathrm{MBF}_{4}(\mathrm{M}=\mathrm{Na}$ and $\mathrm{K})$ melts was studied by Taranenko et al. [25]. The concentration of $\mathrm{MBF}_{4}$ in these melts

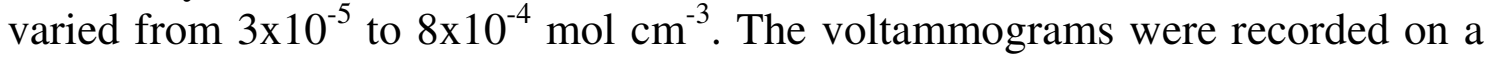
glassy carbon electrode at $973 \mathrm{~K}$. The reduction potential of $\mathrm{B}$ from $\mathrm{B}(\mathrm{III})$, with respect to an $\mathrm{Ag} / \mathrm{AgCl}$ reference electrode, involving a single-step three-electron transfer process, was reported by these authors. The decrease in concentration of the electrochemically active species in the melt with time was reported to be due to chemical reaction of tetrafluoroborate with the chloride melt and (or) by the thermal decomposition of tetrafluoroborate. According to Danek et al. [31], the dissolution of $\mathrm{KBF}_{4}$ in $\mathrm{MCl}(\mathrm{M}=\mathrm{Li}, \mathrm{Na}, \mathrm{K})$ melts was proposed to follow the following exchange reactions:

$$
4 \mathrm{MCl}+\mathrm{KBF}_{4} \leftrightarrows 4 \mathrm{MF}+\mathrm{KBCl}_{4}
$$

The $\mathrm{KBCl}_{4}$ thus formed decomposes according to Eqn. 2 .

$$
\mathrm{KBCl}_{4} \leftrightarrows \mathrm{BCl}_{3} \uparrow+\mathrm{KCl}
$$

The stability of $\mathrm{BF}_{4}{ }^{-}$anions in molten alkali chlorides was reported to increase as $\mathrm{LiCl}<\mathrm{NaCl}<\mathrm{KCl}$ due to the strong polarizing effect of the cation $\left(\mathrm{Li}^{+}>\mathrm{Na}^{+}>\right.$ $\mathrm{K}^{+}$) [25]. Decomposition of $\mathrm{BCl}_{4}{ }^{-}$ions was not observed in $\mathrm{NaCl}$ and $\mathrm{KCl}$ melt system. It was assumed that $\mathrm{MBF}_{4}$ thermally decomposed to gaseous $\mathrm{BF}_{3}$ according to Eqn. 3.

$$
\mathrm{MBF}_{4} \leftrightarrows \mathrm{BF}_{3} \uparrow+\mathrm{MF}
$$

Thermodynamic analysis substantiated that the addition of $\mathrm{F}^{-}$ions to the chloride melts shifted the equilibrium of Eqns. 1 and 3 to the left and consequently suppressed the decomposition of the electrochemically active species. Thus chloride-fluoride supporting electrolyte was better suited compared to pure chloride melts for the electro-deposition of boron.

The aim of the present work is to investigate the electrochemical reduction of boron containing electroactive species in $\mathrm{KCl}-\mathrm{KF}-\mathrm{NaBF}_{4}$ melt and evaluate the kinetic parameters of the electro reduction process. Transient electrochemical techniques such as cyclic voltammetry and chronoamperometry have been used in the present study. 


\section{Experimental}

\section{Materials}

$\mathrm{KCl}(99.5 \%$ purity) and $\mathrm{KF}$ (99 \% purity) were supplied by M/s. Loba Chemie Pvt. Ltd., Mumbai, India. $\mathrm{NaBF}_{4}(>98 \%$ purity) was obtained from M/s. Sigma Aldrich, USA. High-density $\left(1.85 \mathrm{~g} \mathrm{~cm}^{-3}\right)$ graphite was procured from M/s. Pure Components Pvt. Ltd., Pondicherry, India. Platinum wire (1 mm dia., 99.99\% purity) was procured from M/s. Sevantilal Mahasukhlal, Mumbai, India. Inconel 600 (99.9\% purity) which formed the structural material of the electrochemical cell was supplied by M/s. Kalapurna Engineering, Mumbai, India.

\section{Electrochemical studies}

Voltammetric studies were carried out over the temperature range $1073-1123$ K. The electrochemical cell described elsewhere [5] was operated under argon during the measurement. The experiments were conducted using a threeelectrode assembly. A high-density graphite crucible served as the container for the electrolyte as well as the auxiliary electrode. Platinum wire (1 mm diameter) served as the working electrode. The surface area of the Pt electrode dipped in the electrolyte was kept constant at $0.23 \mathrm{~cm}^{2}$ for each measurement. The potentials were measured against an $\mathrm{Ag} / \mathrm{AgCl}$ reference electrode developed in our laboratory [32]. The voltammograms were measured using the electrochemical workstation Autolab (PGSTAT 302N) equipped with an IF 030 interface.

\section{Chronoamperometric studies}

Chronoamperometric measurements were carried out employing a platinum electrode $\left(0.23 \mathrm{~cm}^{2}\right.$ area) by applying potentials ranging from -0.88 to $-0.85 \mathrm{~V}$ for a short duration of $5 \mathrm{~s}$ for the $\mathrm{KCl}(81.54 \mathrm{~mol} \%)-\mathrm{KF}(18.45 \mathrm{~mol} \%)$ melt with $\mathrm{NaBF}_{4}\left(1.67 \times 10^{-4} \mathrm{~mol} \mathrm{~cm}{ }^{-3}\right)$ over the temperature range $1073-1123 \mathrm{~K}$. Chronoamperograms were also measured using Autolab (PGSTAT 302N) equipped with an IF 030 interface.

\section{Analysis of boron in the melt}

After the completion of the voltammetric scans, melt samples were withdrawn from the cell and analyzed. About $10 \mathrm{mg}$ of the solidified melt were dissolved in $10 \mathrm{~mL}$ of $0.02 \mathrm{~N} \mathrm{HNO}_{3}$. The solution was then analyzed for its boron content by inductively coupled plasma mass spectrometer (ICP-MS, Model: Elan 250, M/s. Sciex, Toronto, Canada) after suitable dilution. These measurements had a standard deviation of about 3 to $5 \%$ of the reported value.

\section{Results and discussion \\ Cyclic voltammetry}

The cyclic voltammograms (CV) of the melt $\mathrm{KCl}(81.54 \mathrm{~mol} \%)$-KF (18.45 mol\%) $-\mathrm{NaBF}_{4}\left(1.67 \times 10^{-4} \mathrm{~mol} \mathrm{~cm}{ }^{-3}\right)$ (designated as melt A) were recorded over the temperature range $1073-1123 \mathrm{~K}$. Typical cyclic voltammograms of this melt at various scan rates $\left(0.05-2.0 \mathrm{~V} \mathrm{~s}^{-1}\right)$ are shown in Fig. 1. It is seen that the 
cathodic peak shifts to a more negative potential and the anodic peak shifts to a more positive potential with increasing the scan rates. In addition, the peak current increases with increase in the scan rate.

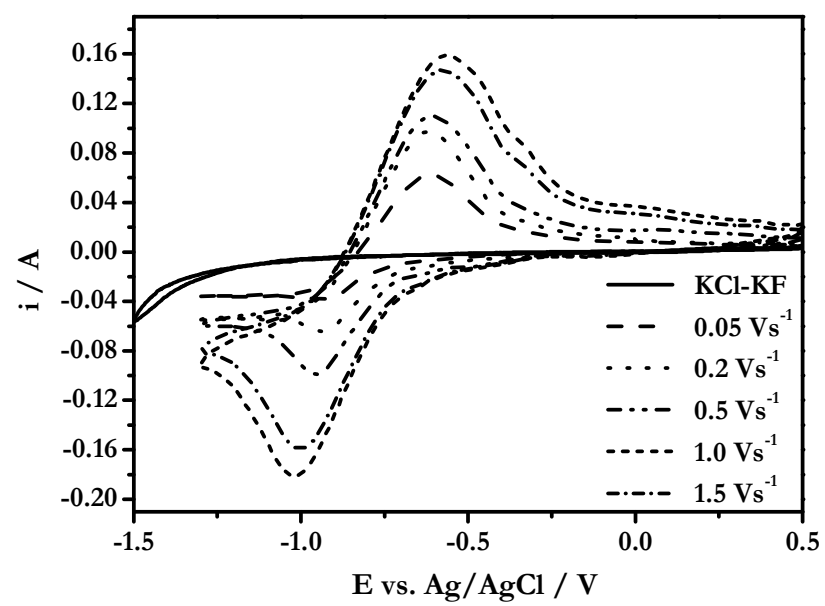

Figure 1. Cyclic voltammetric scans of the melt A on Pt electrode with varying scan rates at $1073 \mathrm{~K}$.

Fig. 2 shows the CVs of melt A at 1073, 1098 and $1123 \mathrm{~K}$. The cathodic $\left(E_{P}^{C}\right)$ and anodic $\left(E_{P}^{A}\right)$ peak potentials of the electroactive species as well as the average of cathodic and anodic peak potentials, $\left(E_{P}^{C}+E_{P}^{A}\right) / 2$, of this melt at different temperatures are given in Table 1. It is observed that the cathodic and anodic peak potentials are shifted to less negative values (Fig. 2) and the average values increase with increase in temperature (Table 1). It is also observed that the magnitude of $E_{P / 2}^{C}-E_{P}^{C}$, ( $E_{P / 2}^{C}$ is cathodic half-peak potential), is larger than the value required for the reversible process of formation of an insoluble substance ( $(0.071 / n) * \mathrm{~V}$ at $1073 \mathrm{~K}$ where, $n$ is the number of electrons transferred for the reduction process) $[33,34]$, indicating that the reduction of boron species on platinum electrode from $\mathrm{KCl}-\mathrm{KF}-\mathrm{NaBF}_{4}$ melt is not reversible.

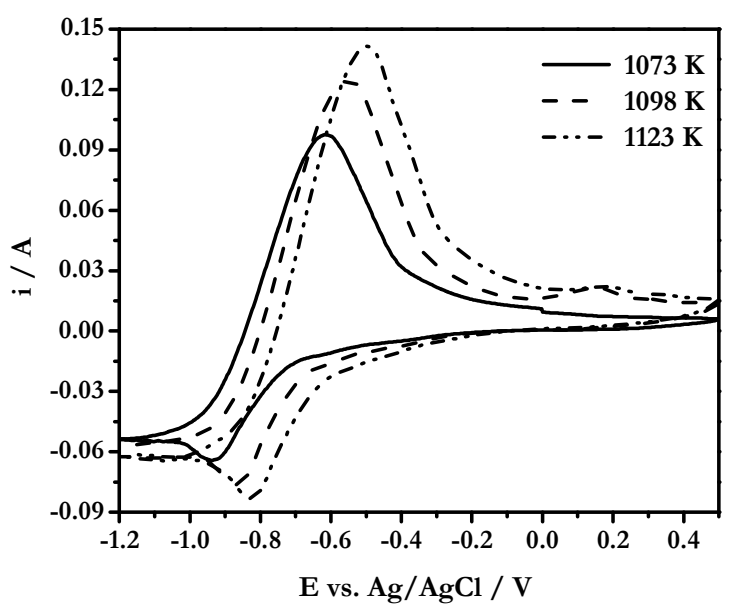

Figure 2. Cyclic voltammetric scans of the melt $\mathrm{A}$ on $\mathrm{Pt}$ electrode at different temperatures (scan rate: $0.2 \mathrm{~V} \mathrm{~s}^{-1}$ ). 
Table 1. Electrokinetic parameters calculated for the electroactive species in the melt A employing the platinum electrode.

\begin{tabular}{|c|c|c|c|c|c|c|c|}
\hline $\begin{array}{l}\text { Temperature } \\
\text { (T/K) }\end{array}$ & $\begin{array}{c}\text { Scan } \\
\text { rate } \\
\left(v / \mathbf{V ~ s}^{-1}\right)\end{array}$ & $\begin{array}{c}\text { Cathodic } \\
\text { peak } \\
\text { potential } \\
\left(\mathbf{E}_{\mathbf{P}} \mathrm{C} / \mathrm{V}\right)\end{array}$ & $\begin{array}{c}\text { Anodic } \\
\text { peak } \\
\text { potential } \\
\left(\mathbf{E}_{\mathbf{P}}^{\mathbf{A}} / \mathbf{V}\right)\end{array}$ & $\left(E_{P}{ }^{C}+E_{P}^{A}\right) / 2(V)$ & $\begin{array}{c}\mathbf{E}_{\mathbf{P} / 2}{ }^{\mathrm{C}}-\mathbf{E}_{\mathrm{P}}{ }^{\mathrm{C}} \\
(\mathbf{V})\end{array}$ & $\begin{array}{c}\alpha \\
\text { from } \\
\text { Eq. } 4\end{array}$ & $\begin{array}{c}\alpha \\
\text { from } \\
\text { Eq. } 5\end{array}$ \\
\hline \multirow[t]{4}{*}{1073} & 0.1 & -0.927 & -0.614 & -0.770 & 0.094 & 0.60 & \\
\hline & 0.5 & -0.955 & -0.608 & -0.781 & 0.118 & 0.48 & \\
\hline & 1.0 & -0.975 & -0.590 & -0.782 & 0.133 & 0.43 & \\
\hline & 2.0 & -1.018 & -0.565 & -0.791 & 0.160 & 0.36 & 0.34 \\
\hline \multirow[t]{4}{*}{1098} & 0.1 & -0.854 & -0.549 & -0.701 & 0.083 & 0.69 & \\
\hline & 0.5 & -0.894 & -0.554 & -0.724 & 0.106 & 0.54 & \\
\hline & 1.0 & -0.925 & -0.542 & -0.733 & 0.125 & 0.46 & \\
\hline & 2.0 & -0.971 & -0.517 & -0.744 & 0.152 & 0.37 & 0.34 \\
\hline \multirow[t]{4}{*}{1123} & 0.1 & -0.786 & -0.493 & -0.639 & 0.089 & 0.64 & \\
\hline & 0.5 & -0.802 & -0.432 & -0.617 & 0.109 & 0.52 & \\
\hline & 1.0 & -0.833 & -0.426 & -0.629 & 0.125 & 0.46 & \\
\hline & 2.0 & -0.879 & -0.394 & -0.636 & 0.149 & 0.38 & 0.31 \\
\hline
\end{tabular}

The reduction potential of boron from boron containing electroactive species in the melt $\mathrm{A}$ was found to be more negative compared to that of melt $\mathrm{KCl}(81.54$ mol\%)-KF (18.45 mol\%)- $\mathrm{KBF}_{4}\left(1.6 \times 10^{-4} \mathrm{~mol} \mathrm{~cm}{ }^{-3}\right)$ (designated as melt B) [5] (Fig. 3).

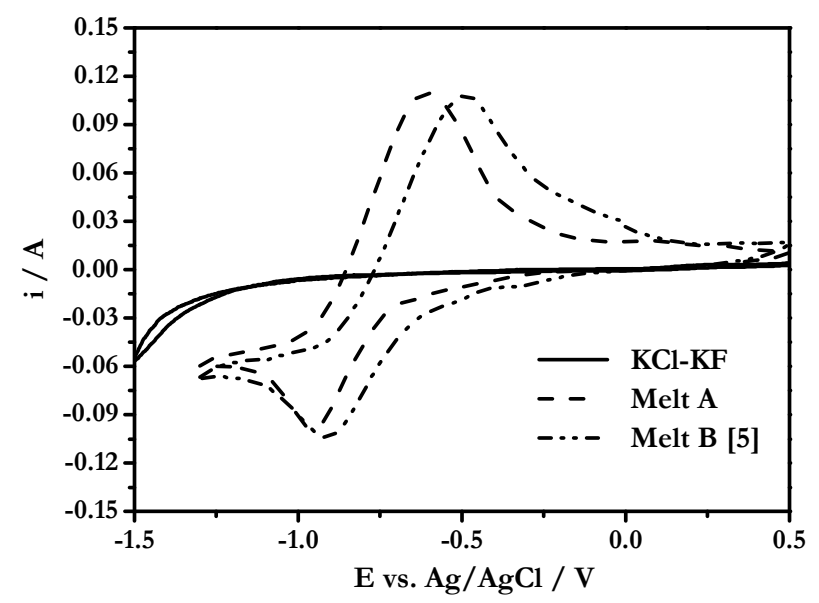

Figure 3. Cyclic voltammetric scans of the melts A and B on Pt electrode at $1073 \mathrm{~K}$ and $0.5 \mathrm{~V} \mathrm{~s}^{-1}$ scan rate.

Fig. 4 shows the plot of $i_{P}^{C} / v^{1 / 2}$ vs. $v^{1 / 2}$ where, $i_{P}^{C}$ is the cathodic peak current and $v$ is the scan rate. It is observed from these plots that for the melt $\mathrm{A}$ at 1073 $\mathrm{K}$, the $i_{P}^{C} / v^{1 / 2}$ values remain almost constant at polarization rate range of 0.05 to $2 \mathrm{~V} \mathrm{~s}^{-1}$. This suggests that the process of electrodeposition of boron on $\mathrm{Pt}$ electrode is not complicated by chemical reactions as suggested by Tsiklauri et al. [35, 36]. In addition, the electrodeposit is not adsorbed at the electrode surface. A similar behaviour was observed for the melts $\mathrm{NaCl}-\mathrm{KCl}-\mathrm{KBF}_{4}$ [24] and melt $\mathrm{B}$ [5]. Thus it can be inferred that the electrodeposition of boron from 
alkali metal fluoroborate containing $\mathrm{KCl}-\mathrm{KF}$ melts is not complicated by chemical reactions.

The variation of $E_{P}^{C}$ with $\log$ arithm of scan rate, $\log v$, at different temperatures for the melt $\mathrm{A}$ is shown in Fig. 5. As seen from the figure, the cathodic peak potential varies linearly with $\log v$. These observations indicate that the reduction of electroactive boron species on platinum electrode is quasi-reversible at low scan rates $\left(v<0.1 \mathrm{Vs}^{-1}\right)$ and irreversible at higher scan rates $\left(>0.1 \mathrm{~V} \mathrm{~s}^{-1}\right)$.

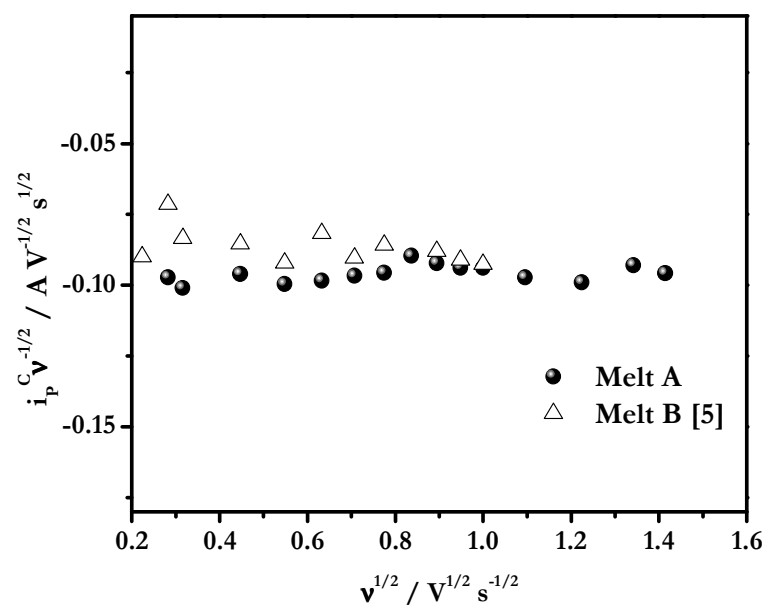

Figure 4. Plot of $i_{P}^{C} / v^{1 / 2}$ vs. $v^{1 / 2}$ for the melts $\mathrm{A}$ and $\mathrm{B}$ at $1073 \mathrm{~K}$.

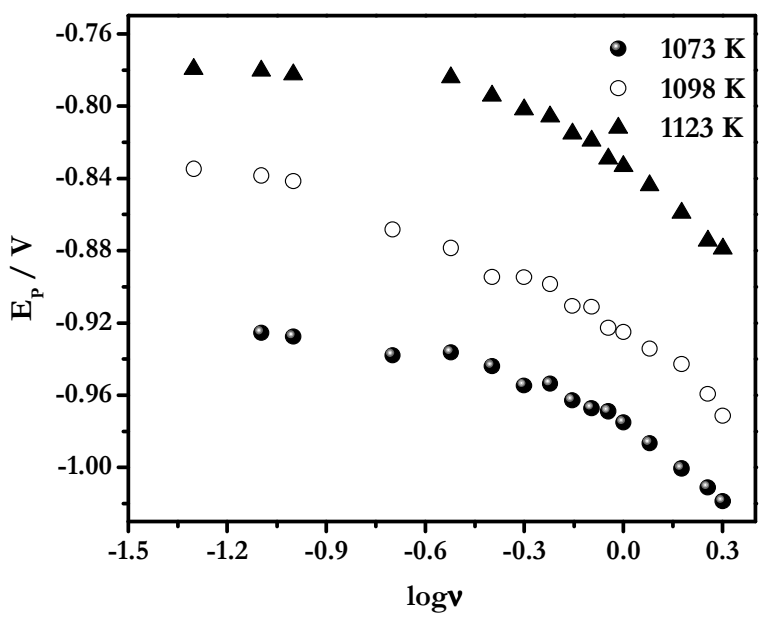

Figure 5. Cathodic peak potential versus logarithm of scan rate measured at different temperatures on a Pt electrode in the melt $\mathrm{A}$.

The variation of the cathodic peak current, $i_{P}^{C}$, with the square root of scan rate, $v^{1 / 2}$, at different temperatures for the melt $\mathrm{A}$ is shown in Fig. 6. The linear relationship between $i_{P}^{C}$ and $v^{1 / 2}$, as observed from these figures indicates that the process is diffusion controlled. 


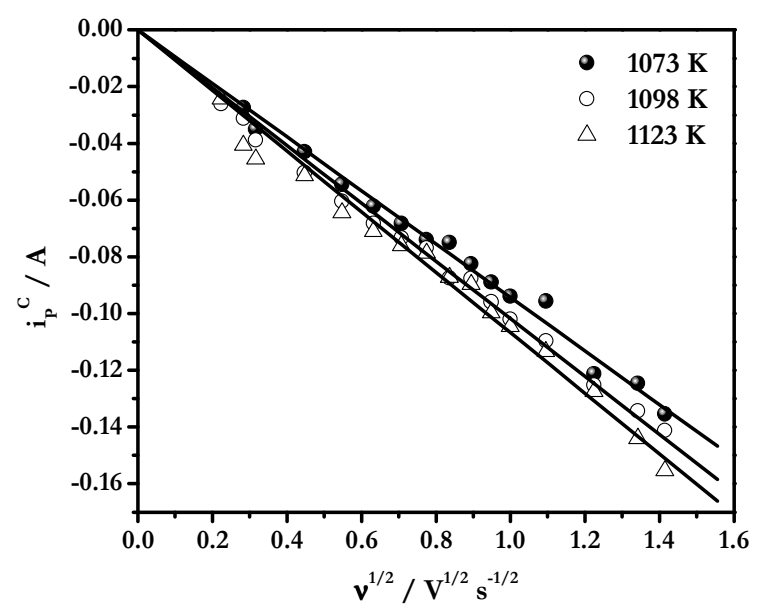

Figure 6. Cathodic peak current versus square root of scan rate at different temperatures on a Pt electrode in the melt $\mathrm{A}$.

\section{Calculation of transfer coefficient}

The value of $\alpha n_{\alpha}$ (where $\alpha$ is the transfer coefficient and $n_{\alpha}$ is the number of electrons transferred for the reduction process in the rate determining step) can be determined from the equation given by Matsuda and Ayabe (Eqn. 4) [37, 38].

$$
E_{P / 2}^{C}-E_{P}^{C}=\frac{1.857 R T}{\alpha n_{\alpha} F}
$$

where $R$ is the molar gas constant, $T$ is the absolute temperature and $F$ is the Faraday constant.

$\alpha n_{\alpha}$ also can be evaluated from the following equation [33].

$$
\frac{\Delta E_{P}^{C}}{\Delta \log v}=\frac{2.3 R T}{2 \alpha n_{\alpha} F}
$$

where $\frac{\Delta E_{P}^{C}}{\Delta \log v}$ is determined from the slope of $E_{P}^{C}$ vs. $\log v$ plots.

The transfer coefficients calculated from Eqns. 4 and 5 for the melt A are given in Table 1. For the melt $\mathrm{A}$ at 1073,1098 and $1123 \mathrm{~K}$ the transfer coefficients were found to vary from $0.60-0.36,0.37-0.69$ and $0.64-0.38$, respectively. By using Eqn. 5 the transfer coefficients for the melt A were found to vary from $0.34-0.31$. The typical transfer coefficient values signify that the process is irreversible. Similar inference has also been drawn for the melt B reported in our previous study [5].

\section{Diffusion coefficients}

The diffusion coefficient of the electroactive species can be measured by chronoamperometry using Cottrell equation (Eqn. 6) [33].

$$
i=\frac{n F A D_{O}{ }^{1 / 2} C_{O}^{*}}{\pi^{1 / 2} t^{1 / 2}}
$$


where $\mathrm{A}$ is the electrode area in $\mathrm{cm}^{2}, C_{0}^{*}$ is the concentration of $\mathrm{B}$ (III) ion in mol $\mathrm{cm}^{-3}, D_{O}$ is the diffusion coefficient in $\mathrm{cm}^{2} \mathrm{~s}^{-1}, F$ is the Faraday constant, $i$ is the current in amperes and $t$ is the transition time in s. Typical chronoamperograms of the melt A employing Pt electrode are shown in Fig. 7.

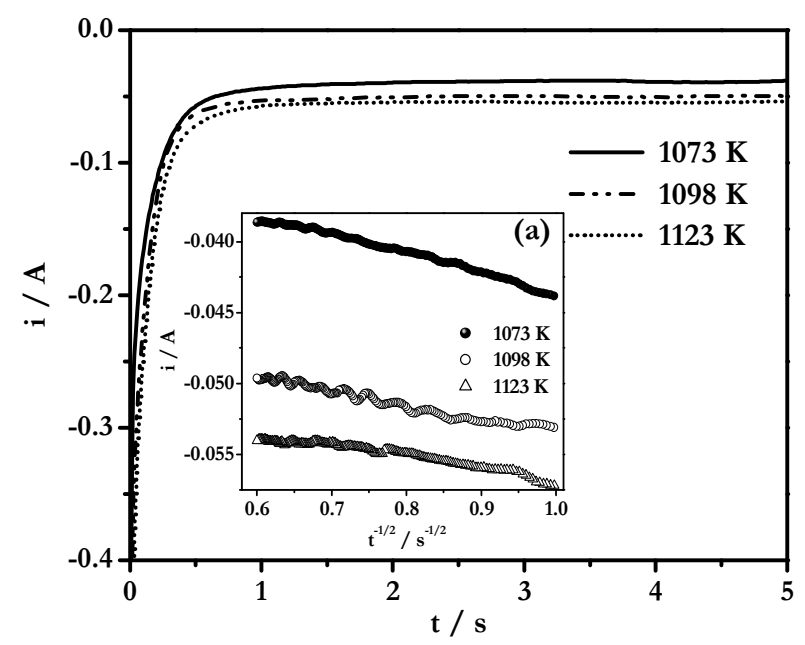

Figure 7. Chronoamperograms of the melt $\mathrm{A}$ on a Pt electrode $\left(0.23 \mathrm{~cm}^{2}\right.$ area $)$ carried out at $-0.85 \mathrm{~V}$ potential scan. The inset (Fig. 7(a)) shows the plot of $i$ vs. $t^{-1 / 2}$.

A linear variation of $i$ with $t^{-1 / 2}$ is observed as shown in Fig. 7(a). This indicates that the reduction of boron containing electroactive species in these melts is diffusion controlled. The diffusion coefficients of the electroactive species in the melt $\mathrm{A}$ were found to be $6.4 \times 10^{-6} \mathrm{~cm}^{2} \mathrm{~s}^{-1}$ at $1073 \mathrm{~K}$ (Table 2). Typical diffusion coefficient values for different alkali metal fluoroborate containing melt system at different temperatures are also presented in Table 2.

Table 2. Diffusion coefficient and electron transfer rate constant of the electroactive species in KCl-KF melts containing different fluoroborates at different temperatures.

\begin{tabular}{cccc}
\hline Melt & Temperature (K) & $\begin{array}{c}\text { Diffusion coefficient } \\
\left(\mathbf{D}_{\mathbf{O}} \mathbf{x} \mathbf{1 0}^{\mathbf{6}} / \mathbf{c m}^{\mathbf{2}} \mathbf{~ s}^{-\mathbf{1}}\right)\end{array}$ & $\begin{array}{c}\text { Electron transfer rate } \\
\text { constant }\left(\mathbf{k}_{\mathbf{s}} \mathbf{x} \mathbf{1 0} / \mathbf{c m ~ s}^{\mathbf{- 1}}\right)\end{array}$ \\
\hline $\mathrm{A}$ & 1073 & 6.4 & 2.0 \\
& 1098 & 7.3 & 1.8 \\
& 1123 & 8.9 & 1.8 \\
$\mathrm{~B}[5]$ & 1073 & 12 & 3.9 \\
& 1098 & 13 & 3.4 \\
& 1123 & 17 & 4.8
\end{tabular}

A comparative study of $D_{O}$ values of the boron containing electroactive species from different alkali metal fluoroborates in $\mathrm{KCl}-\mathrm{KF}$ melt shows that $D_{O}^{\mathrm{NaBF}_{4}}<D_{O}^{\mathrm{KBF}_{4}}$. According to Stokes-Einstein equation (Eqn. 7), the diffusion coefficient of a species is inversely proportional to its solvodynamic radius $\left(r_{s}\right)$.

$$
D_{o}=\frac{k T}{C \pi \eta r_{s}}
$$


where $k$ is the Boltzmann constant, $C$ is a constant and $\eta$ is the absolute or bulk viscosity of the solvent. It is surmised that the solvodynamic radius $\left(r_{s}\right)$ of the boron containing electroactive species varies as $r_{s}^{\mathrm{NaBF}_{4}}>r_{s}^{\mathrm{KBF}_{4}}$ in $\mathrm{KCl}-\mathrm{KF}$ melt containing different alkali metal fluoroborates.

\section{Electron transfer rate constant}

Klingler and Kochi [39] derived an expression (Eqn. 8) for obtaining the electron transfer rate constant $\left(k_{s}\right)$ by assuming that the electron-transfer reaction is irreversible.

$$
k_{s}=2.18\left(\alpha n_{\alpha}\right)^{1 / 2}\left(\frac{D_{O} F v}{R T}\right)^{1 / 2} e^{\frac{\alpha^{2} n F\left(E_{P}^{C}-E_{P}^{A}\right)}{R T}}
$$

By using the above equation the electron transfer rate constants for the irreversible electrode process for sodium fluoroborate in $\mathrm{KCl}-\mathrm{KF}$ melt over the temperature range 1073 to $1123 \mathrm{~K}$ were calculated. The $k_{s}$ values obtained by substituting the $\alpha n_{\alpha}$ values derived from Eqn. 4 at $1 \mathrm{~V} \mathrm{~s}^{-1}$ scan rate and $D_{o}$ from Eqn. 6 are presented in Table 2. These values indicate sluggish electron transfer kinetics due to the fact that the oxidized boron (fluoro-chloro complex of boron) and the reduced boron (elemental boron) are structurally dissimilar and the activation barrier for the redox process is large.

\section{Apparent surface resistance}

Polyakova et al. [34] reported that the broadening of the cathodic peak in CV occurred due to the ohmic control of deposition of boron. These authors presented linear plots of peak current and peak potentials against the square root of scan rate and concluded that a surface boron film formed on the electrode rendered the process to be controlled by ohmic resistance.

The "apparent surface resistance" $\left(R_{a p p}\right)$ of the electrolyte in the pores of the boron film covering the electrode can be obtained from the reciprocal of the slope of peak current density $\left(j_{P}\right)$ vs. peak potential $\left(E_{P}\right)$ plots as reported by Polyakova et al. [34]. The plots for cathodic peak current density vs. cathodic peak potential for the melt A show a linear behavior. The values of $R_{a p p}$ calculated for different fluoroborates in $\mathrm{KCl}-\mathrm{KF}$ melt at different temperatures are presented in Table 3. It is observed (Table 3) that the $R_{a p p}$ values decrease with increase in temperature. Polyakova et al. [34] reported a higher value of $R_{a p p}\left(3.3 \Omega \mathrm{cm}^{2}\right.$ at $\left.973 \mathrm{~K}\right)$ in the melt $\mathrm{LiF}^{\mathrm{N}} \mathrm{NaF}-\mathrm{KF}-\mathrm{KBF}_{4}\left(15.9 \times 10^{-2}\right.$ mol\%). In our earlier study on the melt $\mathrm{B}$, the $R_{\text {app }}\left(0.18 \pm 0.02 \Omega \mathrm{cm}^{2}\right.$ at $\left.1073 \mathrm{~K}\right)$ was found to be of similar magnitude [5]. Thus $R_{a p p}$ was found to be independent of the nature of alkali metal fluoroborate in KCl-KF melt. The typical resistance values obtained (Table 3) in our present study are very small and it is surmised that the effect of resistance on CVs is negligible and it does not quite affect the determination of $\alpha$ values from the cyclic voltammetric scans. 
Table 3. Apparent surface resistance of the electrolyte on the platinum electrode for the melts $\mathrm{A}$ and $\mathrm{B}$ at different temperatures.

\begin{tabular}{ccc}
\hline Melt & Temperature $(\mathbf{K})$ & $\mathbf{R}_{\text {app }}\left(\mathbf{\Omega} \mathbf{~ c m}^{2}\right)$ \\
\hline A & 1073 & $0.21 \pm 0.01$ \\
& 1123 & $0.24 \pm 0.01$ \\
B [5] & 1073 & $0.18 \pm 0.02$ \\
& 1123 & $0.21 \pm 0.01$ \\
\hline
\end{tabular}

\section{Conclusions}

The electrochemical reduction of $\mathrm{B}(\mathrm{III})+3 \mathrm{e} \rightarrow \mathrm{B}$ in $\mathrm{KCl}(81.54 \mathrm{~mol} \%)-\mathrm{KF}$ $(18.45 \mathrm{~mol} \%)-\mathrm{NaBF}_{4}\left(1.67 \times 10^{-4} \mathrm{~mol} \mathrm{~cm}{ }^{-3}\right)$ melt on a Pt electrode was studied by cyclic voltammetry over the temperature range 1073 to $1123 \mathrm{~K}$. It is inferred that at a sweep rate of $v<0.1 \mathrm{Vs}^{-1}$ the electroreduction is quasi-reversible and at $v>$ $0.1 \mathrm{Vs}^{-1}$, both the diffusion of electroactive species and the electron transfer play a role in the reduction process. It is established that the reduction of $\mathrm{B}$ (III) to $\mathrm{B}$ occurs by a single-step three-electron process. Using chronoamperometry, the diffusion coefficients of the boron containing electroactive species (B(III)) were calculated for the sodium fluoroborate melt system and it was found that $D_{O}^{N a B F_{4}}<D_{O}^{K B F_{4}}$. The values of $\alpha$ and $R_{a p p}$ were found to be independent of the nature of alkali metal fluoroborate in $\mathrm{KCl}-\mathrm{KF}$ melt.

\section{Acknowledgements}

The authors are grateful to Mr. R. K. Prabhu for carrying out the ICP-MS analysis.

\section{References}

1. Babu VR, Govindarajan S, Chetal SC. Proc of Seminar on Inherent Engineered Safety Aspects of PFBR Design. IGCAR: Kalpakkam, India; 1996.

2. Suri AK, Subramanian C, Sonber JK, et al. Int Mater Rev. 2010;55:4.

3. Jain A, Anthonysamy S, Ananthasivan K, et al. Mater Charact. 2008;59:890.

4. Pal R, Ananthasivan K, Anthonysamy S, et al. Electrochim Acta. 2012;61:165.

5. Pal R, Anthonysamy S, Ganesan V. J Electrochem Soc. 2012;159:F157.

6. Brotherton RJ, Steinberg H. Progress in boron chemistry. Pergamon Press Inc; 1970. Vol 2.

7. Matkovich VI. Boron and refractory borides. Berlin: Springer Verlag; 1977.

8. Subramanian C, Suri AK. Metal Mater Processes. 2004;16:39.

9. Davidson MG, Hughes AK, Marder TB, et al. Contemporary Boron Chemistry, Royal Society of Chemistry, Cambridge 2000.

10. Kahlenberg HH. Trans Am Electrochem Soc. 1925;47:23.

11. Andrieux L. Ann Chem Phys. 1929;12:432.

12. Andrieux L, Deiss W. Bull Soc Chim. 1955;838 (1955). 
13. Cooper HS. US Patent 2572248;1951.

14. Cooper HS. US Patent 2572249;1951.

15. Russel S, Young FA, Kellner JD. US Patent 3843497;1974.

16. Murphy NF, Tinsley RS. US Patent 2848396;1958.

17. Uchiyama AA, Stern DR, McKenna Q H. US Patent 2940911;1960.

18. Stern DR, McKenna QH. US Patent 2892762;1959.

19. Ellis RB. US Patent 2810683;1957.

20. Nies NP, Fajans EW, Thomas LL, et al. US Patent. 2832730;1958.

21. Nair KU, Bose DK, Gupta CK. Miner Process Extractive Metall Rev. 1992;9:283.

22. Miller GT. J Electrochem Soc. 1959;106:815.

23. Brookes HC, Gibson PS, Hills GJ, et al. Trans Inst Met Finish. 1976;54:191.

24. Kuznetsov SA. Russ J Electrochem. 1996;32:763.

25. Taranenko VI, Zarutskii IV, Shapoval VI, et al. Electrochim Acta. 1992;37:263.

26. Kellner JD. J Electrochem Soc. 1973;120:713.

27. Makyta M, Matiasovsky K, Fellner P. Electrochim Acta. 1984;29:1653.

28. Akashi K, Egami I. Seisan-Kenkyu. 1963;15:427.

29. Newkirk AE. Elemental boron. In: Adams RM, editor. Metallo-boron compounds and boranes. New York. Interscience Publishers; 1964. pp 301371.

30. Kenkyujo S. Japanese Patent. 6243; 1966.

31. Danek V, Votava I, Matiasovsky K. Chem Zvesti. 1976;30:377.

32. Pal R, Ananthasivan K, Anthonysamy S, et al. Electrochim Acta. 2011;56:4276.

33. Bard AJ, Faulkner LR. Electrochemical methods: fundamentals and applications. Wiley, New York; 1980.

34. Polyakova LP, Bukatova GA, Polyakov EG, et al. J Electrochem Soc. 1996;143:3178.

35. Tsiklauri OG, Shapoval VI, Avaliani Ash. Ionnye rasplavy I tverdye elektrolity (Ionic Melts and Solid Electrolytes). 1986;1:47.

36. Tsiklauri OG, Avaliani ASh, Bairammashvili IA. Soobshch. Acad Nauk Gruz SSR. 1989;134:133.

37. Matsuda H, Ayabe Y. Z Electrochem. 1955;59:494.

38. Golovin VA, Dobrenkov GA. Trans Kazan Khim-Tekhnol Inst. 1965;34:202.

39. Klingler RJ, Kochi JK. J Phys Chem. 1981;85:1731. 